\title{
Lanthanides-Substituted Hydroxyapatite/Aloe Vera Composite Coated Titanium Plate for Bone Tissue Regeneration [Retraction]
}

Prabakaran S, Rajan M, Lv C, Meng G. Int J Nanomedicine. 2020;15:8261-8279.

The Editor and Publisher of International Journal of Nanomedicine wish to retract the published article. Concerns were raised regarding alleged image duplication in Figures 9, 12 and 13, specifically:

- Figure 9A appears to have been duplicated with Figure 9B, with decreased magnification, yet the scale bars for each image is the same.

- Figure 12, panel A, HAP Day 1, appears to have been duplicated with panel C, HAP Days 7, with contrast adjustments.

- Figure 12, panel E, MHAP Day 1, appears to have been duplicated with panel O, MHAP/AV Days 7, with contrast adjustments.

- Figure 12, panel L, HAP/AV Days 14, appears to have been duplicated with panel P, MHAP/AV Days 14 , with contrast adjustments.
- Figure 13, panel A, MT Control, appears to have been duplicated with panel C, MT 2nd week, with increased magnification, yet the scale bars for each image is the same and panel D, MT 3rd week.

- Figure 13, panel F, HE Control, appears to have been duplicated with panel H, HE 2nd week, and panel J, HE 4th week.

The authors responded to our queries but were unable to provide a satisfactory explanation or the original data for all the figures. The Editor determined the findings of the study were no longer valid and advised for the article to be retracted.

Our decision-making was informed by our policy on publishing ethics and integrity and the COPE guidelines on retraction.

The retracted article will remain online to maintain the scholarly record, but it will be digitally watermarked on each page as "Retracted".

\section{Publish your work in this journal}

The International Journal of Nanomedicine is an international, peerreviewed journal focusing on the application of nanotechnology in diagnostics, therapeutics, and drug delivery systems throughout the biomedical field. This journal is indexed on PubMed Central, MedLine, CAS, SciSearch ${ }^{\mathbb{B}}$, Current Contents ${ }^{\mathbb{B}} /$ Clinical Medicine,

Journal Citation Reports/Science Edition, EMBase, Scopus and the Elsevier Bibliographic databases. The manuscript management system is completely online and includes a very quick and fair peer-review system, which is all easy to use. Visit http://www.dovepress.com/ testimonials.php to read real quotes from published authors. 